\title{
Condensed Tannin Effects on Nitrogen Digestion in Ruminants: A Meta-analysis from in Vitro and in Vivo Studies
}

\author{
A. Jayanegara ${ }^{*}$ \& E. Palupi ${ }^{\mathrm{b}}$ \\ aDepartment of Nutrition and Feed Technology, Faculty of Animal Science, Bogor Agricultural University \\ Jln. Agatis Kampus IPB Darmaga Bogor 16680 \\ b'International Food Business and Consumer Studies, Faculty of Organic Agricultural Sciences, University of Kassel \\ Steinstrasse 19, D-37213 Witzenhausen, Germany \\ (Received 29-10-2010; accepted 27-12-2010)
}

\begin{abstract}
Statistical meta-analysis approach was conducted to quantify the effect of a wide range of dietary condensed tannin (CT) concentration on nitrogen digestion in ruminants. A total of 19 studies from published papers and own previously unpublished studies comprising of 100 treatments were pooled in a database. The database was segregated into two categories based on different methods or systems where the experiments were carried out, i.e. in vitro (6 studies, 65 treatments) and in vivo experiments (13 studies, 35 treatments). Mixed model effects were applied to the data; different studies were treated as random effects whereas dietary CT (continuous predictor variable) was treated as fixed effects. The results showed that in the in vitro studies, organic matter digestibility (OMD) decreased linearly $(P=0.002)$ as CT concentration in feed increased. Likewise, such linear decrease of OMD at increasing CT was observed in the in vivo studies $(P \varangle 0.001)$ as well as crude protein digestibility (CPD, $P \varangle 0.001)$. The variation on in vitro OMD was higher at lower level of $C T$. Nitrogen retention was not significantly affected by $C T$ level. It was concluded that $C T$ reduced nutrient digestibility in ruminants, but its effect on $\mathrm{N}$ retention was unclear from the present study.
\end{abstract}

Key words: condensed tannin, meta-analysis, nitrogen digestion, ruminant

\section{INTRODUCTION}

A major constraint of ruminant production in tropical countries like Indonesia is the poor quality of feed particularly roughage. Rice straw which contains a considerable proportion of ligno-cellulose and silica (Van Soest, 2006) is commonly fed to the ruminants especially in rural areas. Such practice is often linked to the poor performance and productivity of the animals due to inadequate nutrient supply. Supplementation with concentrate is an option to overcome the problem (Jayanegara \& Sofyan, 2009). However, increasing cost and problem associated with continuous supply of the concentrate may reduce the applicability of such option. In many areas of the tropics, therefore, supplementation using shrubs and tree leaves provide a promising strategy since those roughages are generally rich in crude protein as compared to straws and grasses (e.g. Hess et al., 2008; Camacho et al., 2010).

In addition to its high crude protein content, many shrubs and tree leaves in the tropics contain high con-

* Corresponding author:

E-mail: anu_jayanegara@yahoo.com tents of plant secondary compounds particularly tannins (Mueller-Harvey, 2006; Makkar et al., 2007). Tannins are polyphenolic compounds which are able to interact with other macromolecules such as proteins and carbohydrates. They are divided into two major groups, i.e. hydrolysable and condensed tannins. Hydrolysable tannins are the polymer of gallic or ellagic acid that esterified with sugar molecule, while condensed tannins are polymer of flavonoid compounds (Goel et al., 2005). Condensed tannins are considered to have both detrimental and beneficial effects, depend on the source and concentration applied (Makkar, 2003).

Although there have been a number of experiments conducted to observe the influence of CT on nitrogen digestion of ruminants, the scope was limited in a relatively narrow and limited range of dietary CT concentration. No studies so far have attempted to integrate the findings quantitatively and come out with a more generalized result. In the present study, therefore, a statistical meta-analysis approach (Sauvant et al., 2008) was conducted to quantify the effect of a wide range of dietary condensed tannin concentration on nitrogen digestion in ruminants. To take into account on different methods used in assessing the effect of CT on nitrogen digestion, experiments generated by in vitro and in vivo methods were both considered in the analysis. 


\section{MATERIALS AND METHODS}

\section{Meta-data Development}

A database was constructed from experiments reporting dietary condensed tannins and measuring variables related to $\mathrm{N}$ digestion such as organic matter digestibility (OMD), crude protein digestibility (CPD), $\mathrm{N}$ retention, ammonia $\left(\mathrm{NH}_{3}\right)$ and iso short-chain fatty acids (isoSCFA) production. In addition, other related variables such as bacterial and protozoal counts were also pooled in the database. The database was initially developed to examine the relationship between dietary tannins in general (both condensed and hydrolysable tannins) and ruminal methane production (in vitro and in vivo), of which the results will be published elsewhere.
Condensed tannin forms were either from non-extracted or extracted tannins of plant origins. Studies reporting treatments with addition of polyethylene glycol (PEG) were excluded from the database since the substance may partially or completely neutralize the effects of tannins under rumen environment (Getachew et al., 2001; Jayanegara \& Sofyan, 2008).

A total of 19 studies from published papers and own previously unpublished studies comprising of 100 treatments were pooled in the database (Table 1). Papers reporting more than one experiment were individually encoded. The database was segregated into two categories based on different methods or systems where the experiments were carried out, i.e. in vitro (6 studies, 65 treatments) and in vivo experiments (13 studies, 35 treatments). In vitro studies were conducted using

Table 1. Studies included in the meta-analysis of the effect of condensed tannin concentrations in feeds on nitrogen digestion of ruminants

\begin{tabular}{|c|c|c|c|c|c|c|}
\hline $\begin{array}{l}\text { Study } \\
\text { no. }\end{array}$ & Reference & System & Basal feed & CT source & CT form & $\begin{array}{l}\text { CT level } \\
\text { (g/kg DM) }\end{array}$ \\
\hline 1 & Tavendale et al. (2005) & In vitro & $\left.-^{*}\right)$ & $\begin{array}{l}\text { Medicago sativa, Lotus } \\
\text { pedunculatus }\end{array}$ & Non-extracted & 0.2 and 99.0 \\
\hline 2 & Jayanegara et al. (2009) & In vitro & $\begin{array}{c}\text { Grass hay and barley } \\
\text { straw }\end{array}$ & $\begin{array}{l}\text { Rhus typhina, Salix } \\
\text { alba }\end{array}$ & Non-extracted & 0 to 14.5 \\
\hline 3 & Bhatta et al. (2009) & In vitro & - & Mimosa, quebracho & Extracts & 13.3 to 36.7 \\
\hline 4 & Own study 1 & In vitro & - & $\begin{array}{l}\text { Various tropical } \\
\text { plants }(\mathrm{n}=27)\end{array}$ & Non-extracted & 0 to 86.0 \\
\hline 5 & Own study 2 & In vitro & - & $\begin{array}{l}\text { Various temperate } \\
\text { plants }(\mathrm{n}=18)\end{array}$ & Non-extracted & 0 to 9.0 \\
\hline 6 & Own study 3 & In vitro & $\begin{array}{l}\text { Grass hay and } \\
\text { concentrate }\end{array}$ & Mimosa, quebracho & Purified extract & 0 to 87.7 \\
\hline 7 & Woodward et al. (2002) & In vivo cattle & - & $\begin{array}{l}\text { Hedysarium } \\
\text { coronarium }\end{array}$ & Non-extracted & 0 and 27.2 \\
\hline 8 & Woodward et al. (2004) & In vivo cattle & - & Lotus corniculatus & Non-extracted & 0 and 26.2 \\
\hline 9 & $\begin{array}{l}\text { Pinares-Patino et al. } \\
\text { (2003) }\end{array}$ & In vivo alpaca & - & Lotus corniculatus & Non-extracted & 0.9 and 23.5 \\
\hline 10 & $\begin{array}{l}\text { Pinares-Patino et al. } \\
\text { (2003) }\end{array}$ & In vivo sheep & - & Lotus corniculatus & Non-extracted & 0.8 and 43.6 \\
\hline 11 & Carulla et al. (2005) & In vivo sheep & $\begin{array}{c}\text { Ryegrass, red clover, } \\
\text { alfalfa }\end{array}$ & Acacia mearnsii & Extract & 0 and 25.0 \\
\hline 12 & Puchala et al. (2005) & In vivo goat & - & $\begin{array}{l}\text { Digitaria ischaemum, } \\
\text { Lespedeza cuneata }\end{array}$ & Non-extracted & 5.0 and 177 \\
\hline 13 & Beauchemin et al. (2007) & In vivo cattle & $\begin{array}{l}\text { Barley silage, } \\
\text { concentrate }\end{array}$ & Quebracho & Extract & 0 to 18.2 \\
\hline 14 & De Oliveira et al. (2007) & In vivo cattle & - & Sorghum silage & Non-extracted & 0.2 to 1.0 \\
\hline 15 & Animut et al. (2008a) & In vivo goat & - & $\begin{array}{l}\text { Lespedeza cuneata, } \\
\text { Lespedeza striata }\end{array}$ & Non-extracted & 140 to 151 \\
\hline 16 & Animut et al. (2008b) & In vivo goat & $\begin{array}{l}\text { Sorghum, Sudan } \\
\text { grass }\end{array}$ & Lespedeza striata & Non-extracted & 0.3 to 151 \\
\hline 17 & Tiemann et al. (2008) & In vivo sheep & Palisade grass & $\begin{array}{l}\text { Flemingia macrophylla, } \\
\text { Calliandra calothyrsus }\end{array}$ & Non-extracted & 0 to 32.8 \\
\hline 18 & Grainger et al. (2009) & In vivo cattle & $\begin{array}{l}\text { Ryegrass pasture, } \\
\text { concentrate }\end{array}$ & Acacia mearnsii & Extract & 0 to 18 \\
\hline 19 & $\begin{array}{l}\text { Ramirez-Restrepo et al. } \\
(2010)\end{array}$ & In vivo sheep & - & Salix spp. & Non-extracted & 2.1 and 34.2 \\
\hline
\end{tabular}

$\mathrm{CT}$, condensed tannins

*) The CT sources were not mixed with any of basal feeds. 
Hohenheim gas test, syringe gas generator and glass bottle incubation. For the in vivo database, all ruminant species were included, i.e. alpaca, goat, sheep, and cattle.

\section{Statistical Analysis}

The analysis of the data assembled in the database was made by a statistical meta-analysis approach (Sauvant et al., 2008). Studies were treated as random effects whereas dietary condensed tannins were treated as fixed effects using the procedure MIXED of SAS version 9.2 (SAS Institute Inc., 2008) and using the following model:

$$
Y_{i j}=B_{0}+B_{1} X_{i j}+s_{i}+b_{i} X_{i j}+e_{i j}
$$

where, $\mathrm{Y}_{\mathrm{ij}}=$ dependent variable, $\mathrm{B}_{0}=$ overall intercept from all studies (fixed effect), $\mathrm{B}_{1}=$ linear regression coefficient of $Y$ on $X$ (fixed effect), $X_{i j}=$ value of the continuous predictor variable (dietary condensed tannins), $s_{i}=$ random effect of study $i, b_{i}=$ random effect of study $i$ on the regression coefficient of $Y$ on $X$ in study $i$, and $e_{i j}$ $=$ the unexplained residual errors.

The study variable was declared in the CLASS statement since it did not contain any quantitative information. In addition, an unstructured variance-covariance matrix (type $=$ un) was declared as the random part of the model to avoid the positive correlation between the intercepts and slopes (St-Pierre, 2001). Data were unweighted by the number of replicates in each study (Desnoyers et al., 2009). Presence of outliers was identified by examining studentized residuals; values beyond \pm 3 SD were considered as outliers and, therefore, were removed from the dataset. For graphical presentation of the meta-analysis results, adjustments were made to the response variables to take into account the random effect of study (Patra, 2010).

For the $\mathrm{N}$ retention variable, body size of the ruminants was standardized by relating them to meta-

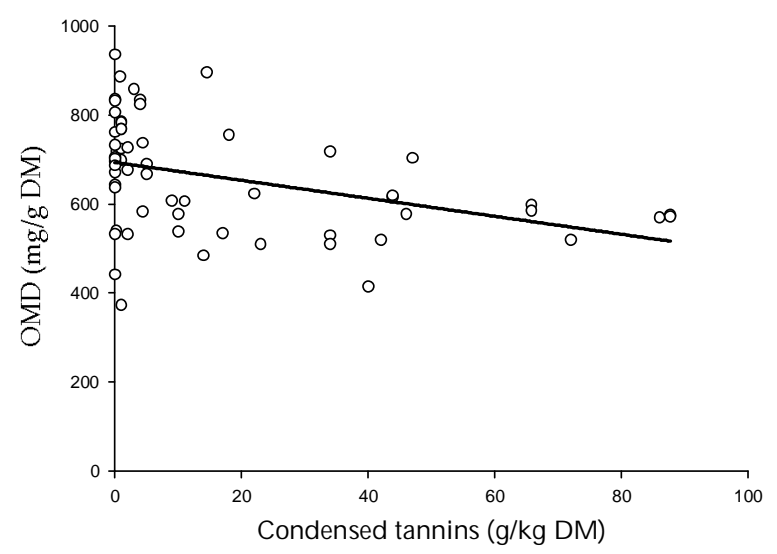

Figure 1. Relationship between dietary condensed tannin concentration and organic matter digestibility in the in vitro studies $\left(\mathrm{OMD}=693.8-2.02 \mathrm{CT}, \mathrm{P}=0.002, \mathrm{R}^{2}=\right.$ $0.160)$. bolic body weight $\left(\mathrm{BW}^{0.75}\right)$ to counterbalance the variation associated with body weight among and within ruminant species. Data reported in different units of measurements were transformed into the same units. Microbial counts variables (both bacterial and protozoal counts) were transformed into their logarithmic units to allow linear relationships with the independent variable. Model statistics presented are $P$-value and coefficient of determination $\left(\mathrm{R}^{2}\right)$. Since the data were unbalance across all variables, meta-analysis was performed based on the available data for each variable.

\section{RESULTS AND DISCUSSION}

\section{Effects on Digestion and Ruminal Fermentation}

In the in vitro studies, organic matter digestibility (OMD) decreased linearly $(P=0.002)$ as $C T$ concentration in feed increased (Figure 1). Likewise, such linear decrease of OMD at increasing CT was observed as well in the in vivo studies $(P<0.001)$ (Figure 2$)$. The results indicated that the nutrient digestibility was clearly hampered by increasing level of CT as confirmed by both in vitro and in vivo studies. This might be connected to a theory that tannins form complexes with natural polymers such as proteins and carbohydrates (McSweeney et al., 2001; Makkar, 2003; Mueller-Harvey, 2006; Jayanegara et al., 2009) and, therefore, may reduce their digestibility in the digestive tract of ruminants. The binding property of tannins is resulted from a large number of free phenolic groups that form strong hydrogen bonds at multiple sites with proteins (Silanikove et al., 2001). Tannins may also form complexes with proteins through hydrophobic binding between the aromatic ring structure of tannins and hydrophobic regions of the proteins (Smith et al., 2005). Additionally, covalent bonds may also be formed between protein and tannins through oxidative polymerization reactions as a result of heating, exposure to UV radiation and the action of polyphenol oxidase (Reed,

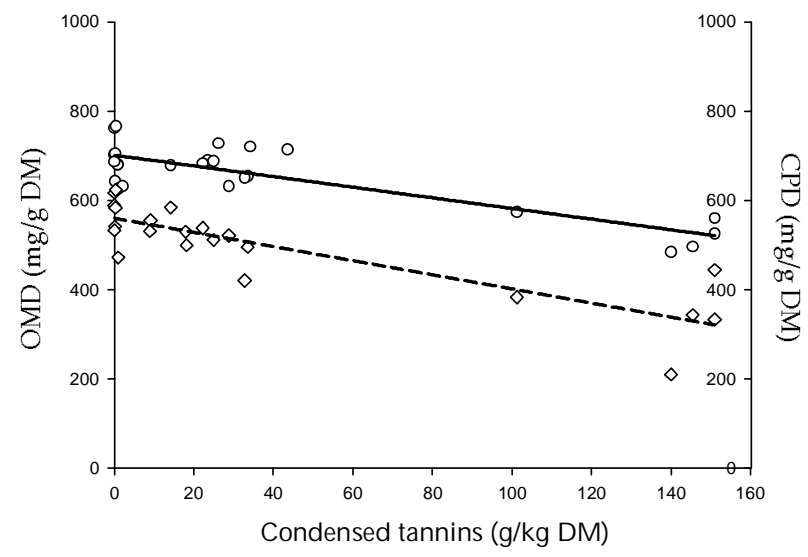

Figure 2. Relationships between dietary condensed tannin concentration and organic matter digestibility (-O-, full regression line; $\mathrm{OMD}=701.2$ - 1.19 CT, $\mathrm{P} \varangle 0.001$, $\left.\mathrm{R}^{2}=0.701\right)$ and crude protein digestibility $\left(-\vee_{-}\right.$, dashed regression line; $\mathrm{CPD}=559.7-1.59 \mathrm{CT}, \mathrm{P}<0.001, \mathrm{R}^{2}=$ 0.730 ) in the in vivo studies. 


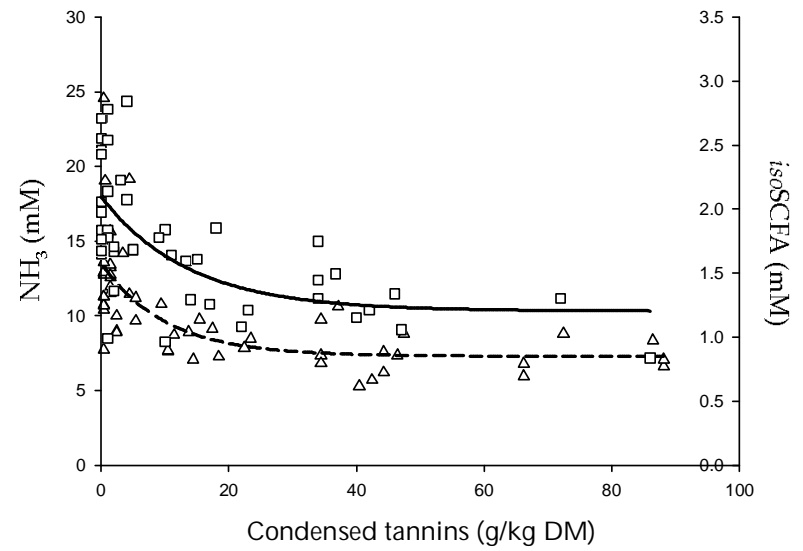

Figure 3. Relationships between dietary condensed tannin concentration and ruminal $\mathrm{NH}_{3}(-\square-$, full regression line; $\left.\mathrm{NH}_{3}=10.3+7.66 \mathrm{e}^{-0.073 \mathrm{CT}}, \mathrm{P} \varangle 0.001, \mathrm{R}^{2}=0.443\right)$ and isoSCFA $(-\Delta-$, dashed regression line; isoSCFA $=0.85+$ $\left.0.70 \mathrm{e}^{-0.099} \mathrm{CT}, \mathrm{P}<0.001, \mathrm{R}^{2}=0.48\right)$ concentrations in the in vitro studies.

1995). It is of interest to note that the variation on in vitro OMD was higher at lower level of CT. This may be addressed as an explanation on the inconsistency effect of $\mathrm{CT}$ on nitrogen digestion at low level of application.

From the in vivo studies, crude protein digestibility (CPD) decreased as CT level increase, and the relationship was stronger than that of OMD. This suggests that CT may have a stronger interaction with protein than those of other organic components in the diet, particularly fiber fractions. In agreement with McSweeney et al. (2001), higher negative effect of dietary tannins on $\mathrm{CP}$ digestibility than that of fiber suggests that the effect of tannins on fiber digestion is a secondary effect as compared to its effect on protein digestion. Protein appears to have more possible binding sites with tannins than that of fiber since fiber appears to interact with tannins through only hydrogen bonds (Silanikove et al., 2001); protein may also complex with tannins through hydrophobic binding and covalent bonds as discussed above. It may be possibly also that proteolytic bacteria are more tannin sensitive than those of fiber degrading bacteria. This is perhaps supported by the work of

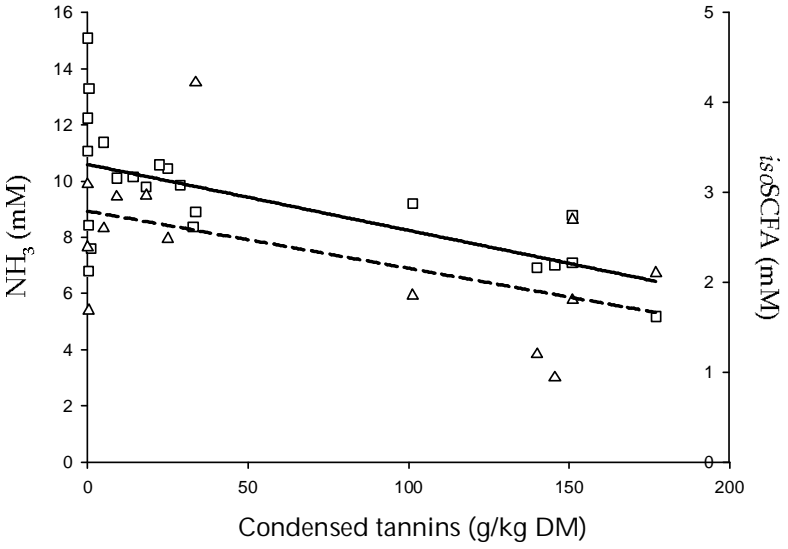

Figure 4. Relationships between dietary condensed tannin concentration and ruminal $\mathrm{NH}_{3}(-\square-$, full regression line; $\left.\mathrm{NH}_{3}=10.6-0.024 \mathrm{CT}, \mathrm{P}=0.002, \mathrm{R}^{2}=0.40\right)$ and isoSCFA $(-\Delta-$, dashed regression line; isoSCFA $=2.79$ $\left.-0.006 \mathrm{CT}, \mathrm{P}=0.051, \mathrm{R}^{2}=0.281\right)$ concentrations in the in vivo studies.

Min et al. (2002) who observed that condensed tannins in Lotus corniculatus reduced the populations of some proteolytic bacteria, but total ruminal microbial protein were remain unchanged.

The negative effect of CT on CP digestibility was supported by the results from $\mathrm{NH}_{3}$ and isoSCFA variables. During ruminal digestion and fermentation, protein is degraded by certain microbes to result $\mathrm{NH}_{3}$. IsoSCFA, mainly comprised of isobutyrate and isovalerate, are also connected to protein degradation in the rumen. They are the specific products from deamination of branched chain amino acids (Hoffmann et al., 2008). Therefore, these variables could be used as indicators for the extent of protein degradation in the rumen. Ruminal $\mathrm{NH}_{3}(P<0.001)$ and isoSCFA production $(P \varangle 0.001)$ decreased with the increasing level of $\mathrm{CT}$ in the in vitro studies (Figure 3). However, the decrease was not linear. Instead, both curves followed exponential decay models and stabilized after around $40 \mathrm{~g} / \mathrm{kg} \mathrm{CT}$. Different pattern was observed from the in vivo studies. Within this type of studies, ruminal $\mathrm{NH}_{3}(P=0.002)$ and isoSCFA $(P=0.051)$ decreased linearly as increasing level of CT (Figure 4).

Table 2. Equations for linear regression of dietary condensed tannin (in $\mathrm{g} / \mathrm{kg} \mathrm{DM}$ ) on microbial counts and nitrogen retention

\begin{tabular}{|c|c|c|c|c|c|c|c|}
\hline \multirow{2}{*}{ Response variable } & \multirow{2}{*}{$\mathrm{n}$} & \multicolumn{6}{|c|}{ Variable estimates } \\
\hline & & Intercept & SE intercept & $P$ intercept & Slope & SE slope & $P$ slope \\
\hline \multicolumn{8}{|l|}{ In vitro studies } \\
\hline Log bacteria & 45 & 9.49 & 0.024 & 0.002 & 0.002 & 0.0006 & $<0.001$ \\
\hline Log protozoa & 48 & 4.36 & 0.080 & $<0.001$ & 0.001 & 0.0008 & ns \\
\hline \multicolumn{8}{|l|}{ In vivo studies } \\
\hline Log bacteria & 9 & 10.34 & 0.374 & 0.001 & -0.001 & 0.0022 & ns \\
\hline Log protozoa & 13 & 5.87 & 0.160 & $<0.001$ & -0.001 & 0.0014 & ns \\
\hline Nitrogen retention $(\mathrm{g} / \mathrm{d})$ & 13 & 2.18 & 1.346 & ns & 0.013 & 0.0099 & ns \\
\hline
\end{tabular}

$\mathrm{n}$, number of observation; ns, not significant at $\mathrm{P}<0.05$; SE, standard error. 


\section{Effects on Microbial Counts and Nitrogen Retention}

Increasing CT level in feed led to a linear increase in $\log$ bacterial counts from the in vitro studies $(P<0.001)$, although the increase was quite small (Table 2). However, the significance could not be observed in the in vivo studies. Log protozoal counts were not significantly affected by CT concentrations in both in vitro and in vivo studies. This is in agreement with Makkar (2003) who stated that the effects of tannins on protozal counts are variable. Such result might be related to a view that holotrichs seem to be more susceptible to tannins than those of entodiniomorphs (Makkar et al., 1995; Carulla et al., 2005) although the population of holotrichs is much lower. So, the large pool of protozoa appears to be not that sensitive to the presence of tannins in the rumen. In addition to such inconsistent effect of CT on ruminal protozoa, Patra \& Saxena (2009) suggested that tannins present in all types of plants are not equally effective on protozoa.

Interestingly, although CT was shown to have a negative effect on ruminal nitrogen digestion, it did not significantly affect nitrogen retention in the body of ruminants. This could be possibly due to the high variability of $\mathrm{N}$ retention over different CT levels. Tannins may reduce the amount of protein that is degraded in the rumen and increase the amount of available protein in the small intestine or known as ruminal by-pass protein (Min et al., 2003). Therefore, lower $\mathrm{N}$ absorption in the rumen may occur and shifted towards higher $\mathrm{N}$ flow to the small intestine. As the consequence, lower urinary $\mathrm{N}$ and higher faecal $\mathrm{N}$ could be expected. However, tannins have complicated and great structural diversity. This implies to the diverse activity of tannins and even slight changes in the structures can produce measurable effects (Mueller-Harvey, 2006). It is then unsurprising that the $\mathrm{N}$ retention is quite variable in the presence of CT.

\section{CONCLUSION}

Dietary condensed tannins reduced organic matter digestibility linearly in both in vitro and in vivo studies. At low level of $\mathrm{CT}$, the variation on in vitro OMD was higher. This was supported by the results from $\mathrm{NH}_{3}$ and isoSCFA variables in the both types of studies; ruminal $\mathrm{NH}_{3}$ and isoSCFA decreased with increasing level of dietary CT. No clear effects of CT on microbial (bacterial and protozoal) counts were observed. Although CT was shown to have a negative effect on ruminal nitrogen digestion, it did not significantly affect nitrogen retention in the body of ruminants.

\section{REFERENCES}

Animut, G., R. Puchala, A. L. Goetsch, A. K. Patra, T. Sahlu, V. H. Varel, \& J. Wells. 2008a. Methane emission by goats consuming different sources of condensed tannins. Anim. Feed Sci. Technol. 144: 228-241.

Animut, G., R. Puchala, A. L. Goetsch, A. K. Patra, T. Sahlu, V. H. Varel, \& J. Wells. 2008b. Methane emission by goats consuming diets with different levels of condensed tannins from lespedeza. Anim. Feed Sci. Technol. 144: 212-227.

Beauchemin, K. A., S. M. McGinn, T. F. Martinez, \& T. A. McAllister. 2007. Use of condensed tannin extract from quebracho trees to reduce methane emissions from cattle. J. Anim. Sci. 85: 1990-1996.

Bhatta, R., Y. Uyeno, K. Tajima, A. Takenaka, Y. Yabumoto, I. Nonaka, O. Enishi, \& M. Kurihara. 2009. Difference in nature of tannins on in vitro ruminal methane and volatile fatty acid production and on methanogenic archaea and protozoal populations. J. Dairy Sci. 92: 5512-5522.

Camacho, L.M ., R. Rojo, A. Z. M. Salem, G. D. Mendoza, D. Lopez, J. L. Tinoco, B. Albarran, \& O. D. MontanezValdez. 2010. In vitro ruminal fermentation kinetics and energy utilization of three Mexican tree fodder species during the rainy and dry period. Anim. Feed Sci. Technol. 160: $110-120$.

Carulla, J. E., M. Kreuzer, A. Machmüller, \& H. D. Hess. 2005. Supplementation of Acacia mearnsii tannins decreases methanogenesis and urinary nitrogen in forage-fed sheep. Aust. J. Agric. Res. 56: 961-970.

De Oliveira, S. G., T. T. Berchielli, M. S. Pedreira, O. Primavesi, R. Frighetto, \& M. A. Lima. 2007. Effect of tannin level in sorghum silage and concentrate supplementation on apparent digestibility and methane emission in beef cattle. Anim. Feed Sci. Technol. 135: 236-248.

Desnoyers, M., S. Giger-Reverdin, G. Bertin, C. DuvauxPonter, \& D. Sauvant. 2009. Meta-analysis of the influence of Saccharomyces cerevisiae supplementation on ruminal parameters and milk production of ruminants. J. Dairy Sci. 92: 1620-1632.

Getachew, G., H. P. S. Makkar, \& K. Becker. 2001. Method of polyethylene glycol application to tannin-containing browses to improve microbial fermentation and efficiency of microbial protein synthesis from tannin-containing browses. Anim. Feed Sci. Technol. 92: 51-57.

Goel, G., A. K. Puniya, C. N. Aguilar \& K. Singh. 2005. Interaction of gut microflora with tannins in feeds. Naturwissenschaften 92: 497-503.

Grainger, C., T. Clarke, M. J. Auldist, K. A. Beauchemin, S. M. McGinn, G. C. Waghorn, \& R. J. Eckard. 2009. Potential use of Acacia mearnsii condensed tannins to reduce methane emissions and nitrogen excretion from grazing dairy cows. Can. J. Anim. Sci. 89: 241-251.

Hess, H. D., M. L. Mera, T. T. Tiemann, C. E. Lascano, \& M. Kreuzer. 2008. In vitro assessment of the suitability of replacing the low-tannin legume Vigna unguiculata with the tanniniferous legumes Leucaena leucocephala, Flemingia macrophylla or Calliandra calothyrsus in a tropical grass diet. Anim. Feed Sci. Technol. 147: 105-115.

Hoffmann, E. M., N. Selje-Assmann, \& K. Becker. 2008. Dose studies on anti-proteolytic effects of a methanol extract from Knautia arvensis on in vitro ruminal fermentation. Anim. Feed Sci. Technol. 145: 285-301.

Jayanegara, A. \& A. Sofyan. 2008. Penentuan aktifitas biologis tannin beberapa hijauan secara in vitro menggunakan Hohenheim Gas Test dengan polietilen glikol sebagai determinan. Med. Pet. 31: 44-52.

Jayanegara, A. \& A. Sofyan. 2009. Supplementary feeding on the nutrient balance of lactating dairy cow at contrasting temperature regimes: assessment using Cornell Net Carbohydrate and Protein System (CNCPS) model. J. Indon. Trop. Anim. Agric. 34: 196-204.

Jayanegara, A., A. Sofyan, H. P. S. Makkar, \& K. Becker. 2009. Kinetika produksi gas, kecernaan bahan organik dan produksi gas metana in vitro pada hay dan jerami yang disuplementasi hijauan mengandung tanin. Med. Pet. 32: 120-129. 
Makkar, H. P. S., M. Blümmel, \& K. Becker. 1995. In vitro effects of and interactions between tannins and saponins and fate of tannins in the rumen. J. Sci. Food Agric. 69: 481-493.

Makkar, H. P. S. 2003. Effects and fate of tannins in ruminant animals, adaptation to tannins, and strategies to overcome detrimental effects of feeding tannin-rich feeds. Small Rum. Res. 49: 241-256.

Makkar, H. P. S., G. Francis, \& K. Becker. 2007. Bioactivity of phytochemicals in some lesser-known plants and their effects and potential applications in livestock and aquaculture production systems. Animal 1: 1371-1391.

McSweeney, C. S., B. Palmer, D. M. McNeill, \& D. O. Krause. 2001. Microbial interactions with tannins: nutritional consequences for ruminants. Anim. Feed Sci. Technol. 91: 83-93.

Min, B. R., G. T. Attwood, K. Reilly, W. Sun, J. S. Peters, T. N. Barry, \& W. C. McNabb. 2002. Lotus corniculatus condensed tannins decrease in vivo populations of proteolytic bacteria and affect nitrogen metabolism in the rumen of sheep. Can. J. Microbiol. 48: 911-921.

Min, B. R., T. N. Barry, G. T. Attwood, \& W. C. McNabb. 2003. The effect of condensed tannins on the nutrition and health of ruminants fed fresh temperate forages: a review. Anim. Feed Sci. Technol. 106: 3-19.

Mueller-Harvey, I. 2006. Unravelling the conundrum of tannins in animal nutrition and health. J. Sci. Food Agric. 86: 2010-2037.

Patra, A. K. \& J. Saxena. 2009. Dietary phytochemicals as rumen modifiers: a review of the effects on microbial populations. Antonie van Leeuwenhoek 96: 363-375.

Patra, A. K. 2010. Effects of supplementing low-quality roughages with tree foliages on digestibility, nitrogen utilization and rumen characteristics in sheep: a meta-analysis. J. Anim. Physiol. Anim. Nutr. 94: 338-353.

Pinares-Patino, C. S., M. J. Ulyatt, G. C. Waghorn, K. R. Lassey, T. N. Barry, C. W. Holmes, \& D. E. Johnson. 2003. Methane emission by alpaca and sheep fed on lucerne hay or grazed on pastures of perennial ryegrass/white clover on birdsfoot trefoil. J. Agric. Sci. 140: 215-226.

Puchala, R., B. R. Min, A. L. Goetsch, \& T. Sahlu. 2005. The effect of a condensed tannin-containing forage on methane emission by goats. J. Anim. Sci. 83: 182-186.

Ramirez-Restrepo, C. A., T. N. Barry, A. Marriner, N. Lopez-
Villalobos, E. L. McWilliam, K. R. Lassey, \& H. Clark. 2010. Effects of grazing willow fodder blocks upon methane production and blood composition in young sheep. Anim. Feed Sci. Technol. 155: 33-43.

Reed, J. D. 1995. Nutritional toxicology of tannins and related polyphenols in forage legumes. J. Anim. Sci. 73: 1516-1528.

SAS Institute Inc. 2008. SAS STAT Software, version 9.2. SAS Institute Inc., Cary, USA.

Sauvant, D., P. Schmidely, J. J. Daudin, \& N. R. St-Pierre. 2008. Meta-analyses of experimental data in animal nutrition. Animal 2: 1203-1214.

Silanikove, N., A. Perevolotsky, \& F. D. Provenza. 2001. Use of tannin-binding chemicals to assay for tannins and their negative post-ingestive effects in ruminants. Anim. Feed Sci. Technol. 91: 69-81.

Smith, A. H., E. Zoetendal, \& R. I. Mackie. 2005. Bacterial mechanisms to overcome inhibitory effects of dietary tannins. Microb. Ecol. 50: 197-205.

St-Pierre, N. R. 2001. Integrating quantitative findings from multiple studies using mixed model methodology. J. Dairy Sci. 84: 741-755.

Tavendale, M. H., L. P. Meagher, D. Pacheco, N. Walker, G. T. Attwood, \& S. Sivakumaran. 2005. Methane production from in vitro rumen incubations with Lotus pedunculatus and Medicago sativa, and effects of extractable condensed tannin fractions on methanogenesis. Anim. Feed Sci. Technol. 123-124: 403-419.

Tiemann, T. T., C. E. Lascano, H. R. Wettstein, A. C. Mayer, M. Kreuzer, \& H. D. Hess. 2008. Effect of tropical tanninrich shrub legumes Calliandra calothyrsus and Flemingia macrophylla on methane emission and nitrogen and energy balance in growing lambs. Animal 2: 790-799.

Van Soest, P. J. 2006. Rice straw, the role of silica and treatments to improve quality. Anim. Feed Sci. Technol. 130: 137-171.

Woodward, S. L., G. C. Waghorn, K. R. Lassey, \& P. G. Laboyrie. 2002. Does feeding sulla (Hedysarium coronarium) reduce methane emissions from dairy cows? Proc. NZ Soc. Anim. Prod. 62: 227-230.

Woodward, S. L., G. C. Waghorn, \& P. G. Laboyrie. 2004. Condensed tannins in birdsfoot trefoil (Lotus corniculatus) reduce methane emissions from dairy cows. Proc. NZ Soc. Anim. Prod. 64: 160-164. 